\title{
О роли доктрины в современном международном праве
}

Ашавский Б.М. ${ }^{*}$

В статье обсуждаются актуальные теоретические и практические аспекты роли доктрины в современном международном праве. С одной стороны, доктрина рассматривается автором как система взглядов и концепций о сущности международного права в конкретных исторических условиях. С другой, - учения наиболее квалифицированных специалистов по публичному праву различных наций анализируются как вспомогательное средство для определения правовых норм.

Ключевые слова: доктрина международного права; кодификация международного права; определение правовых норм; наиболее квалифицированные специалисты по публичному праву различных наций.

Понятие доктрины в международном праве неоднозначно. Так, в Словаре международного права говорится о том, что термин «доктрина международного права» в широком смысле означает систему взглядов и концепций о сущности международного права в конкретных исторических условиях, а в узком - научные труды юристов-международников ${ }^{1}$. Далее сказано о том, что доктрина международного права является вспомогательным источником международного пра$\mathrm{Ba}^{2}$. В современную эпоху с этим утверждением нельзя согласиться, поскольку доктрина может использоваться лишь в качестве вспомогательного средства для определения правовых норм, а не как источник международного права, пусть даже к вспомогательный. Для подтверждения этой мысли, как правило, используют один и тот же аргумент: подпункт «d» пункта 1 статьи 38 Статута Международного суда. Действительно, это единственный международно-правовой документ договорного характера, в котором содержится, хотя и в общем виде, легальное основание для такого вывода. В ст. 38, в частности, закреплено, что международные конвенции, международный обычай, общие прин-

\footnotetext{
* Ашавский Борис Матвеевич - к.ю.н., с.н.с., ведущий научный сотрудник Центра международного права и международной безопасности Института актуальных международных проблем, профессор ДА МИД России.

1 Словарь международного права. М., 1986. С. 76.

2 Там же.
} 
ципы права и Сразу же следует сказать, что содержащаяся в этой статье оговорка не случайна и имеет принципиальный характер, поскольку в ст. 59 закреплено, что . Иными словами, решения Суда не создают норм общего международного права. То, что в ст. 38 говорится о специалистах по не вызывает сомнений в том, что речь, в силу контекста, идет о специалистах по То же самое, по той же причине относится и к : имеются в виду И в том, и в другом случае иных толкований не возникает. Бесспорно также и то, что необходимость в определении может возникнуть и возникает лишь в отношении обычных норм международного права. Причем «определение» в данном случае означает необходимость как установить существование таких норм, так и уточнить их содержание. Как писал известный австрийский професcop А. Фердросс, доктрина служит «для уяснения сомнительных положений (международного. - Б.А.) права»³.

Немецкий юрист-международник В. Витцтум считает, что доктрины в первую очередь «служат тому, чтобы доказать существование практики, имеющей обязательную силу» ${ }^{4}$.

«Доктрины наиболее квалифицированных специалистов по публичному праву различных наций» подразумевают научные труды наиболее известных и авторитетных юристов-международников из различных государств. Это научные авторитеты в своих странах и за рубежом, авторы курсов международного права, специальные докладчики Комиссии международного права ООН, признанные специалисты по отдельным международно-правовым проблемам.

Однако, если выйти за рамки Статута Международного суда и оценить значение и роль международно-правовой доктрины более широко, некоторые утверждения, которые прозвучали выше, оказываются не столь однозначными и бесспорными.

А. Фердросс приводил мнение Блюдорна, который полагал, что международное право по преимуществу является «правом ученых». Соглашаясь с ним в том, что «отдельные авторы в области международного права оказали большое влияние на образование позитивного международного права», он считал, что «их теории не могут рассматриваться как самостоятельный источник (международного. - Б.А.) права». Тем более не согласился он с утверждением Блюдорна, согласно

3 Фердросс А. Международное право. Пер. с немецкого / Под ред. и с пред. д.ю.н. Г.И.Тункина. М., 1959. С. 165.

${ }^{4}$ Международное право / В.Витцтум и др. Пер. с немецкого. М., 2011. С. 98. 
которому в качестве источников права следует рассматривать заключения научных объединений (Institut de droit international, International Law Association), поскольку, как правило, в задачу таких заключений «не входит установление позитивного международного права, а лишь содействие его дальнейшему развитию» ${ }^{5}$. По мнению не менее известного английского юриста-международника Я. Броунли, «по некоторым вопросам отдельные авторы оказали на (международное. - Б.А.) право формирующее воздействие» ${ }^{6}$. Он называет среди них Жиделя, Холла, Оппенгейма, Хайда, Гугенхейма, Фердросса, Руссо, Ваттеля, Кальво, Хакворта, Филимора и Финлея. Тем не менее для него «совершенно очевидно, что оценка доктринальных концепций зависит от субъективных факторов, что отдельные авторы отражают в своих трудах национальные и иные пристрастия и что, кроме того, некоторые ученые-юристы усматривают свою задачу в пропаганде новых и более правильных взглядов, а не в пассивном описании существующего международного права» ${ }^{7}$. В то же время «при всей необходимости осторожного подхода мнения специалистов по (международному - Б.А.) публичному праву используются широко» ${ }^{8}$.

В. Витцтум считает что «значение научной доктрины проистекает из ее исторической роли. Однако международно-правовые концепции ученых различных стран и культурных сообществ в настоящее время с трудом согласуются друг с другом. Следствием является возрастающее значение коллективных мнений и коллективных заявлений международных ассоциаций юристов» ${ }^{9}$. Среди таких организаций он называет Институт международного права и Ассоциацию международного права. Здесь он вступает в определенное противоречие с приведенным выше мнением А. Фердросса.

Как отмечал профессор Г.И. Тункин, «в XIX и даже в начале XX века многие юристы (-международники. - Б.А.) рассматривали международное право как в значительной мере «доктринальное» право, «право ученых». Они приписывали науке международного права не только роль его констататора, но и роль создателя его норм» ${ }^{10}$.

\footnotetext{
5 Фердросс А. Указ. соч. С. 165.

6 Броунли Я. Международное право. Пер. с английского / Под ред. и со вступ. статьей члена-корреспондента АН СССР Г.И. Тункина. М., 1977. С. 54.

7 Там же. С. 55.

${ }^{8}$ Там же.

9 Международное право. В.Витцтум и др. С. 98.

10 Тункин Г.И. Теория международного права. М., 1970. С. 211.
} 
В период, когда международное право преимущественно было правом обычным, доктрина международного права играла гораздо большую роль, нежели в современных условиях, в которых международное право стало в основном договорным и роль международно-правового обычая значительно уменьшилась.

Тем не менее выводы Г.И. Тункина по этому вопросу не теряют своей актуальности. В частности, о том, что «мнения авторитетных специалистов по международному праву различных стран являются ныне одним из средств установления наличия или отсутствия тех или иных норм международного права, а также их толкования» ${ }^{11}$. Важно понимать также, что доктрина хотя и не является частью процесса образования международно-правовых норм, но оказывает на него определенное влияние. Она играет значительную роль в процессе кодификации международного права, при формировании международно-правовой позиции государства по тем или иным вопросам. Например, при подготовке и в процессе работы международных конференций и организаций.

Таким образом, доктрина играет определенную роль не только в процессе применения международного права, но и в процессе его развития.

Международное право и научные представления о нем (концепции и доктрина в целом) тесно взаимосвязаны. Континуум оценок его роли в современном мире простирается от полного отрицания до явного завышения. То же самое можно сказать и относительно оценок роли доктрины международного права. В этих условиях более чем необходим реалистичный подход. Он несомненно должен найти отражение прежде всего в концепции внешней политики Российской Федерации и, что еще важнее, в самой внешней политике России. Международное право, являясь регулятором международных отношений, выполняет две неразрывно связанные и взаимопроникающие функции: стабилизирующую и созидательную. Оно закрепляет уже сложившиеся отношения, а также служит их изменению или перестройке ${ }^{12}$. При этом необходимо учитывать объективные пределы его действия, связанные со спецификой создания и действия международно-правовых норм, особенно в таких областях, как поддержание международного мира и безопасности, в которых многое зависит от соотношения сил в мире.

\footnotetext{
${ }^{11}$ Тункин Г.И. Там же.

12 Тункин Г. Разрядка напряженности и международное право // Коммунист. 1974, № 11. C. 111.
} 
Доктрина международного права может оказывать существенное воздействие на его развитие. Поддерживая основные принципы и нормы, выступая против отживших концепций, доктрина может внести значительный вклад в развитие международного права.

\section{Библиографический список}

Броунли Я. Международное право. Пер. с английского / Под ред. и со вступ. статьей члена-корреспондента АН СССР Г.И. Тункина. М., 1977.

Международное право / В.Витцтум и др. Пер. с немецкого. М., 2011. Словарь международного права. М., 1986.

Тункин Г. Разрядка напряженности и международное право // Коммунист. 1974., № 11. С. 111.

Тункин Г.И. Теория международного права. М., 1970.

Фердросс А. Международное право. Пер. с немецкого / Под ред. и с пред. д.ю.н. Г.И.Тункина. М., 1959. 


\section{Role of the Doctrine in the Contemporary International Law (Summary)}

Boris M. Ashavsky*

The article deals with theoretical and practical aspects of the role of the doctrine in the contemporary international law. On the one hand, the author considers the doctrine as a system of views and purposes of international law in concrete historical conditions. On the other hand, the author analyzes the role of the teachings of the most highly qualified publicists of the various nations as subsidiary means for the determination of rules of law.

Keywords: the doctrine of international law; codification of international law; the determination of rules of law; the most highly qualified publicists of various nations.

\footnotetext{
* Boris M. Ashavsky - Ph.D. in Law, professor of the Diplomatic Academy, MFA Russia; principle researcher at the center of International law and security of the Institute of Contemporary International Studies.
} 